\title{
Association of Oral Disease with 12 Selected Variables: II. Edentulism
}

\author{
CHESTER J. SUMMERS and ALBERT OBERMAN* \\ School of Dentistry and School of Public Health. University of Michigan, \\ Ann Arbor, Michigan
}

\begin{abstract}
Twelve variables of a group of edentulous subjects were compared with those of dentulous subjects in a probability sample of 408 persons, ages $\geq 20$ years, living in $T e$ cumseh. Michigan. Bronchitis and heart disease were also considered in relation to edentulism and to the 12 variables in question.
\end{abstract}

It has been estimated that $18 \%$ of the adult population of the United States is edentulous. ${ }^{1}$ Epidemiologically, however, little is known about the edentulous. This report describes some of the characteristics of a group of edentulous persons and compares them with those of dentulous persons. Of the social and physiologic measurements obtained during the initial investigation in the Tecumseh Community Health Study,2,3 12 variables were used for this comparison.

For the purposes of this report, an edentulous subject was defined as any adult, at least 20 years of age, who had no teeth visible in the oral cavity. According to previous reports, ${ }^{1,4}$ the percentage of adults who are edentulous, not including those who are edentulous in only one arch, rises from less than $10 \%$ at the age of 40 to more than $50 \%$ at age 65 .

Reports of tooth mortality ${ }^{\bar{i}-\tau}$ have indicated that dental caries accounts for $60 \%$ of all teeth lost in persons less than 35 years of age, whereas periodontal disease accounts for nearly $80 \%$ of all teeth lost in persons more than 35 years of age.

This investigation was supported in part by USPHS Fellowship 1-F3-DE-34, 946-01 from the National Institute of Dental Research and by USPHS Fellowship 1-F3-HE-33, 537-01 from the National Heart Institute, National Institutes of Health, Bethsda, Md.

Received for publication November 8, 1967.

* Present address: Department of Public Health and Epidemiology. The University of Alabama Medical Center, Birmingham. Ala.

\section{Materials and Methods}

Tecumseh, Michigan, and its surrounding area were chosen as a suitable site to study a complete natural community, including the population and its biological, physical, and social environment. ${ }^{3}$ As part of this investigation, complete medical histories were taken and physical examinations, electrocaridograms, and selected laboratory tests were performed on the population during 1959 to 1960 . In addition, Jamison ${ }^{8}$ examined a $10 \%$ geographically stratified random sample, comprising 801 people, to determine the prevalence and severity of periodontal disease. Of those eligible for the dental study, $690(86 \%)$ participated.

The study sample of the present report consists of 408 persons, 20 years old or more, for on whom dental and medical information was available. Of these, 84 people were edentulous and 324 were dentulous.

A preliminary anaylsis indicated that the dentulous persons could be described better if they were allotted to three groups on the basis of their periodontal disease index (PDI) score. ${ }^{9-10}$ The groups were constructed so that they would be roughly equal in size and so that one group would consist of persons with PDI scores greater than 4.0. These scores represented individuals with loss of epithelial attachment who were considered as having advanced periodontal disease (Table 1).

The variables used in the analyses were age, height, weight, relative weight, systolic blood pressure, diastolic blood pressure, blood glucose, serum cholesterol, serum uric acid, one-second forced expiratory volume $\left(\mathrm{FEV}_{1}\right), *$ alcohol consumption, and cigarette consumption. The methodology and

\footnotetext{
* FEV $V_{3}$ is a measure of pulmonary obstruction and used as an index of chronic obstructive lung disease.
} 
TABLE 1

Frequency Distribution of the Study Sample, ACCORDING TO GROUP

\begin{tabular}{lcccr}
\hline \hline & & \multicolumn{3}{c}{ No. per Group } \\
\cline { 3 - 5 } \multicolumn{1}{c}{ Group } & PDI Score & Men & Women & Total \\
\hline Dentulous & & & & \\
I & $0.0-2.9$ & 28 & 53 & 81 \\
II & $3.0-3.9$ & 43 & 59 & 102 \\
III & $4.0-6.0$ & 83 & 58 & 141 \\
Edentulous & & 39 & 45 & 84 \\
IV & $\ldots \ldots$ & 39 & & \\
\hline
\end{tabular}

procedures used in the investigation have been described. ${ }^{11}$

In a preliminary investigation of the study sample, these physiologic variables were significantly correlated with age $(p<0.01)$ : height, relative weight, systolic blood pressure, diastolic blood pressure, blood glucose, serum cholesterol, and $\mathrm{FEV}_{1}$. Weight and serum uric acid were significantly correlated with age $(p<0.05)$.

When attempting any comparisons of these groups by a variable highly correlated with age, it was necessary to adjust for age. The simplest way to do this was to standardize the score for each variable of each subject to that which is typical of his agesex group. ${ }^{12}$ Substitutions into this formula give an age-sex standardized score for each person:

$\left(\begin{array}{l}\text { observed score of } \\ \text { individual subject }\end{array}\right)-\left(\begin{array}{l}\text { mean score of his } \\ \text { age-sex group }\end{array}\right)$

$\left.\begin{array}{c}\text { (standard deviation of the variable } \\ \text { for his age-sex group }\end{array}\right)$

A value of 10.0 was added arbitrarily to the standardized score to eliminate negative values. The mean score and standard deviation of each age-sex group for each physiologic variable were available from the Tecumseh Community Health Study. ${ }^{11}$

The social variables (alcohol consumption and cigarette consumption) were not age-sex standardized in the analyses because the preliminary investigation revealed that these variables were not significantly correlated with age $(0.50>p>0.25)$.

The analysis of variance test ( $F$ test) was used to test the differences among the groups for both the physiologic and social variables.

Because bronchitis may be a possible source for focal infection, coronary disease may affect periodontal disease, ${ }^{9}$ and diabetes may increase susceptibility to infection, the prevalence of these diseases in the dentulous and edentulous groups was studied.

\section{Results}

AGE.-The distribution of the study sample according to age and sex (Table 2) indicated that the mean age increased for both sexes from group I to group IV. The dentulous groups, groups I to III, were much younger as a whole ( 39.0 years) than the edentulous group, group IV (55.3 years). In the edentulous group, the women were 7.3 years younger on the average than the men; whereas, in the dentulous group, the women were only 0.4 years younger on the average than the men.

Physiologic VARIABLEs.-The means of the standardized scores and standard deviations of the observations of each group for

TABLE 2

Age Distribution of the Study Sample, According to Group and Sex

\begin{tabular}{|c|c|c|c|c|c|c|c|c|c|}
\hline \multirow[b]{2}{*}{ Sex } & \multicolumn{7}{|c|}{ Age (Years) } & \multirow[b]{2}{*}{ Total } & \multirow{2}{*}{$\begin{array}{l}\text { Mean Age for } \\
\text { Each Group }\end{array}$} \\
\hline & $20-29$ & $30-39$ & $40-49$ & $50-59$ & $60-69$ & $70-79$ & $>80$ & & \\
\hline $\begin{array}{l}\text { Group I } \\
\text { Male } \\
\text { Female }\end{array}$ & $\begin{array}{l}12 \\
24\end{array}$ & $\begin{array}{l}14 \\
20\end{array}$ & $\frac{1}{7}$ & $\begin{array}{l}1 \\
2\end{array}$ & $\begin{array}{l}0 \\
0\end{array}$ & $\begin{array}{l}0 \\
0\end{array}$ & $\begin{array}{l}0 \\
0\end{array}$ & $\begin{array}{l}28 \\
53\end{array}$ & $\begin{array}{l}30.4 \\
31.6\end{array}$ \\
\hline $\begin{array}{l}\text { Group II } \\
\text { Male } \\
\text { Female }\end{array}$ & $\begin{array}{l}10 \\
14\end{array}$ & $\begin{array}{l}19 \\
27\end{array}$ & $\begin{array}{r}8 \\
11\end{array}$ & $\begin{array}{l}6 \\
3\end{array}$ & $\begin{array}{l}0 \\
4\end{array}$ & $\begin{array}{l}0 \\
0\end{array}$ & $\begin{array}{l}0 \\
0\end{array}$ & $\begin{array}{l}43 \\
59\end{array}$ & $\begin{array}{l}35.8 \\
36.8\end{array}$ \\
\hline $\begin{array}{l}\text { Group III } \\
\text { Male } \\
\text { Female }\end{array}$ & $\begin{array}{l}7 \\
5\end{array}$ & $\begin{array}{l}23 \\
15\end{array}$ & $\begin{array}{l}30 \\
13\end{array}$ & $\begin{array}{l}13 \\
11\end{array}$ & $\begin{array}{l}8 \\
9\end{array}$ & $\begin{array}{l}2 \\
3\end{array}$ & $\begin{array}{l}0 \\
2\end{array}$ & $\begin{array}{l}83 \\
58\end{array}$ & $\begin{array}{l}44.0 \\
47.6\end{array}$ \\
\hline $\begin{array}{l}\text { Group IV } \\
\text { Male } \\
\text { Female } \\
\text { Total }\end{array}$ & $\begin{array}{r}1 \\
1 \\
74\end{array}$ & $\begin{array}{r}4 \\
11 \\
133\end{array}$ & $\begin{array}{r}7 \\
11 \\
88\end{array}$ & $\begin{array}{r}9 \\
6 \\
51\end{array}$ & $\begin{array}{r}6 \\
6 \\
33\end{array}$ & $\begin{array}{r}8 \\
10 \\
23\end{array}$ & $\begin{array}{l}4 \\
0 \\
6\end{array}$ & $\begin{array}{r}39 \\
45 \\
408\end{array}$ & $\begin{array}{c}59.3 \\
52.0 \\
\ldots\end{array}$ \\
\hline
\end{tabular}


TABLE 3

Means of the Age-Sex Standardized Scores and Standard Deviations of the Orservations for Nine Phystologic Vartables, According to Group

\begin{tabular}{|c|c|c|c|c|c|c|c|c|c|}
\hline \multirow[b]{2}{*}{ V'ariables } & \multicolumn{2}{|c|}{ Group 1} & \multicolumn{2}{|c|}{ Group II } & \multicolumn{2}{|c|}{ Group III } & \multicolumn{2}{|c|}{ Group $1 V$} & \multirow{2}{*}{$\begin{array}{c}\text { Signiti- } \\
\text { cant } \\
\text { Dilfer- } \\
\text { ence } \\
\text { Among } \\
\text { Groug }\end{array}$} \\
\hline & Mean & $\mathrm{SD}$ & Mean & $S D$ & Mean & $S D$ & Mean & $S D$ & \\
\hline Height & 10.3 & 1.42 & 10.4 & 1.22 & 10.2 & 1.23 & 10.3 & 1.29 & NS \\
\hline Weight & 9.6 & 0.92 & 9.9 & 0.87 & 9.9 & 1.02 & 9.9 & 1.04 & NS \\
\hline Relative weight & 9.8 & 0.80 & 9.8 & 0.85 & 9.8 & 1.11 & 9.8 & 0.87 & NS \\
\hline Systolic blood pressure & 10.0 & 1.10 & 9.9 & 1.07 & 9.8 & 0.93 & 9.9 & 0.97 & NS \\
\hline Diastolic blood pressure & 9.9 & 0.86 & 10.0 & 1.08 & 9.8 & 0.86 & 9.8 & 0.94 & NS \\
\hline Blood glucose & 10.0 & 0.97 & 10.0 & 1.00 & 10.1 & 1.10 & 9.9 & 1.21 & NS \\
\hline Serum cholesterol & 9.9 & 0.80 & 10.1 & 1.21 & 10.0 & 0.88 & 10.1 & 0.92 & NS \\
\hline Serum uric acid & 9.8 & 0.84 & 9.7 & 0.87 & 9.7 & 0.94 & 9.6 & 1.00 & NS \\
\hline $\mathrm{FEV}_{1}$ & 9.9 & 0.88 & 10.0 & 0.91 & 9.7 & 1.03 & 9.7 & 0.86 & Sig.* \\
\hline
\end{tabular}

NS, Not significant

* Significant at 0.05 level $\left(\mathrm{F}_{3,4 m}\right)$.

each physiologic variable are given (Table $3)$. There were no differences in the mean standardized scores among the four groups for height, weight, relative weight, systolic blood pressure, diastolic blood pressure. blood glucose, serum cholesterol, and serum uric acid. There was significant difference among the groups for $\mathrm{FEV}_{1}$ at the 0.05 level. The lowest mean scores for $\mathrm{FEV}_{1}$ were in the edentulous group and in the dentulous group with the high PDI scores. Except for $\mathrm{FEV}_{1}$, the mean values for the physiologic variables were the same for the dentulous and edentulous groups.

Social variabies.-The means and standard deviations of each group for the social variables of alcohol consumption and cigarette consumption are presented according to sex (Table 4). Alcohol consumption is given in units of alcohol per week (one unit $=5$ $\mathrm{gm}$ of alcohol). The mean rates for alcohol consumption among the four groups were not significantly different in men or in wom- en but, within each group, the mean rate for men was significantly higher than the mean rate for women. The mean rate for alcohol consumption in edentulous men was higher than that in dentulous men; in contrast, the mean rate in edentulous women was lower than that in dentulous women.

Cigarette consumption is given in packs smoked per day. The mean rates for cigarette consumption among the four groups were not significantly different in women but were so in men at the 0.01 level of significance. Groups III and IV had much higher mean rates than groups I and II. Within each group, the mean rate for cigarette consumption in men was significantly higher than in women.

SySTEMIC DISEASE IN THE STUdY SAMPLE. - The prevalence of bronchitis was twice as high in the edentulous persons (21 of 84 ; $25 \%$ ) compared with the dentulous persons (44 of $324 ; 13 \%$ ). When the percentages were adjusted for age, however, there was

TABLE 4

Means and Standard Deviations of the Observations for Two Social Variables, According to Group and Sex

\begin{tabular}{|c|c|c|c|c|c|c|c|c|c|}
\hline \multirow[b]{2}{*}{$\operatorname{Sex}$} & \multicolumn{2}{|c|}{ Group ! } & \multicolumn{2}{|c|}{ Group [I } & \multicolumn{2}{|c|}{ Group III } & \multicolumn{2}{|c|}{ Group IV } & \multirow{2}{*}{$\begin{array}{c}\text { Signiticant } \\
\text { Difference } \\
\text { Among } \\
\text { Groups }\end{array}$} \\
\hline & Mean & $S D$ & Nean & $\mathrm{SD}$ & Mean & $\mathrm{sin}$ & Mean & SD & \\
\hline \multicolumn{10}{|c|}{ Alcohol consumption } \\
\hline Male & 1.65 & 1.74 & 1.53 & 1.28 & 1.79 & 1.70 & 2.11 & 2.04 & NS \\
\hline Female & 0.46 & 1.04 & 0.70 & 1.14 & 0.63 & 1.23 & 0.33 & 0.70 & NS \\
\hline \multicolumn{10}{|c|}{ Cigarette consumption } \\
\hline Male & 0.31 & 0.62 & 0.58 & 0.66 & 0.85 & 0.79 & 0.73 & 0.75 & Sig. * \\
\hline Female & 0.19 & 0.37 & 0.27 & 0.47 & 0.38 & 0.46 & 0.33 & 0.63 & NS \\
\hline
\end{tabular}

NS, Not significant.

* Significant at 0.01 level. 
TABLE 5

Duration of Edentulism, According to SeX

\begin{tabular}{lccccccc}
\hline & \multicolumn{9}{c}{ Duration of Edentulism (Years) } & \multicolumn{1}{c}{$\begin{array}{c}\text { Not } \\
\text { Sex }\end{array}$} & $0-9$ & $10-19$ & $20-29$ & $30-39$ & $\mathbf{4 0 - 4 9}$ & $\begin{array}{c}\text { Average Years } \\
\text { Ascertained } \\
\text { of Edentulism }\end{array}$ \\
\hline Male & 16 & 16 & 3 & 1 & 2 & 1 & 11.8 \\
Female & 20 & 14 & 9 & 2 & 0 & 0 & 12.8 \\
Total & 36 & 30 & 12 & 3 & 2 & 1 & 12.3 \\
\hline
\end{tabular}

no significant difference between the edentulous $(14 \%)$ and dentulous (16\%) persons.

The prevalence of coronary heart disease was more than twice as great in the edentulous persons, (6 of $84 ; 7 \%$ ), compared with the dentulous persons ( 9 of $324 ; 3 \%$ ). When the percentages were adjusted for age, however, there was no significant difference in the rates between the edentulous $(4.5 \%)$ and dentulous $(2.8 \%)$ persons.

Diabetes was diagnosed only in one person, an edentulous man; therefore, no comparisons could be made among the groups.

LENGTH OF TIME EDENTULOUS.-The mean length of time the edentulous had been without their natural teeth (Table 5) was 11.8 years for men and 12.8 years for women, with most persons (78\%) having been without their teeth for less than 20 years.

\section{Discussion}

The findings indicate that most differences found between the edentulous and dentulous groups are probably related to an age difference of 16 years. Using age-sex standardized scores for the physiologic variables, there were no differences among the groups with respect to systolic blood pressure, diastolic blood pressure, blood glucose, serum cholesterol, and serum uric acid, all risk factors associated with coronary heart disease.

The presence of bronchitis and low $\mathrm{FEV}_{1}$ scores are indexes of impaired pulmonary function, but the $\mathrm{FEV}_{1}$ score is the more sensitive index. When age was adjusted, the edentulous group and the dentulous group with the high PDI scores had lower scores for $\mathrm{FEV}_{1}$ than the dentulous groups with the low and medium PDI scores. A relationship, therefore, may exist between edentulism, severe periodontal disease, and impairment of pulmonary function.

Preliminary findings ${ }^{9}$ have indicated that smoking is inversely related to $F E V_{1}$. The edentulous men and the dentulous men with the high PDI scores smoked more than the men in the remaining groups. It seems logical, then, that smoking may be a common factor to $\mathrm{FEV}_{1}$ and to edentulism and severe periodontal disease, although no cause and effect can be stated.

Although an age effect might be attributed to the increased use of alcohol in edentulous men, an age effect was not seen in edentulous women.

The analyses of the findings in this report are restricted by small sample size and the lack of information about periodontal disease prior to loss of teeth as well as about the causes of edentulism. Only a prospective longitudinal study of wide scope can provide basic information, which is surprisingly absent from the dental literature. Areas of exploration that might be most fruitful in longitudinal studies were emphasized in this report.

\section{Conclusion}

A $10 \%$ probability sample from Tecumseh, Michigan, consisted of 408 people, 20 years old or more, of whom 84 were edentulous. These 84 people were compared with dentulous persons on the basis of selected variables. For purposes of analyses, the dentulous subjects were allotted into three groups on the basis of their PDI scores.

Because the edentulous people were significantly older than the dentulous people, and all physiologic variables were significantly correlated with age, the scores for each physiological variable were age-sex standardized.

Among the physiologic variables studied, the $\mathrm{FEV}_{1}$ differed significantly between the dentulous and edentulous groups. When the social variables were considered, edentulous men consumed more alcohol than dentulous men, but the reverse was true for women. In men, the edentulous group and the dentulous group with the greatest evidence of periodontal disease had significantly greater ciga- 
rette consumption than men in the groups with medium or little evidence of periodontal disease.

When the prevalences of bronchitis and coronary heart disease were age-adjusted, there were no significant differences between the dentulous and edentulous persons.

The dental data were collected by Homer C. Jamison; the medical data are reported for the research staff of the Cardiovascular Research Center, The University of Michigan (Thomas Francis, Jr., director).

\section{References}

1. Public Health Service, National Center for Health Statistics: Selected Dental Findings in Adults by Age, Race, and Sex: United States 1960-1962, Public Health Service Publication 1000, Series 11, No. 7, Washington, DC, 1963 , pp 6-7.

2. NAPIER, J.A.: Field Methods and Response Rates in the Tecumseh Community Health Study, Amer I Public Health 52:208-216, 1962.

3. Francis, T., Jr., and Epstein, F.H.: Tecumseh, Michigan, Milbank Mem Fund Quar 43:333-342, 1965.

4. Fulton, J.T.; Hughes, J.T.; and Mercer, C.V.: The Life Cycle of Human Teeth, Chapel Hill: University of North Carolina, School of Public Health, 1964, p 33.

5. Andrews, G., and Krogh, H.W.: Perma- nent Tooth Mortality, Dent Prog 1:130$134,1961$.

6. Davis, C.H.: Relative Causes of Tooth Mortality, Public Health Dent 21:85-91, 1961.

7. Pelton, W.J.; Pennell, E.H.; and DruZINA, A.: Tooth Morbidity Experience of Adults, $J$ Amer Dent Assoc 49:439-445. 1954.

8. JAMISON, H.C.: Prevalence and Severity of Periodontal Disease in a Sample of a Population, thesis, University of Michigan, School of Public Health, Ann Arbor, 1960.

9. Summers, C.J., and Oberman, A.: Association of Oral Diseases with 12 Selected Variables: I. Periodontal Disease, $J$ Dent Res 47:457-462, 1968.

10. RAMFJoRd, S.P.: Indices for Incidence and Prevalence of Periodontal Disease. I Periodont 30:51-59, 1959.

11. Tecumseh Community Health Study: Statistical Tables: Means, Standard Deviations, Ranges and Selected Percentiles for 15 Variables by Age and Sex, Mimeo, University of Michigan, School of Public Health, Ann Arbor, 1959-1960.

12. Mikkelsen; W.M., Dodge, H.J.; and ValKENBURG, H.: The Distribution of Serum Uric Acid Values in a Population Unselected as to Gout or Hyperuricemia, Amer $J$ Med 39:242-251, 1965. 